\title{
FINANCING SUSTAINABLE DEVELOPMENT: ALLEVIATING LIVELIHOODS IN THE FOREST SECTOR WITH SIERRA LEONE AS A CASE STUDY
}

\author{
JACKSON Emerson Abraham ${ }^{1}$ \\ University of Birmingham,EAJ392@bham.ac.uk
}

\begin{abstract}
Sustainable development concept has been associated with many things, as in this situation with "Payment for Environmental Services [PES]"; a modern invention craving attention across the world, and more so for the benefit of those in developing nations around Asia, Latin America and Africa. Financing of sustainable development schemes require scope for enhancing sustained maintenance of basic livelihoods for everyone [both in the present and future], but more so for those whose lives have been heavily dependent on renewable forest resources. The concept of PES has been exemplified in a simple way to enable readers [of all types, ranging from professionals, academics to non-professionals] to grasp basic concepts that bothers on economics and natural resource concepts, and their application in understanding the varied sources of funding sustainable means of livelihoods, while at the same time ensuring the environment is securely protected for the benefit of both present and future generations. To start with, an introduction to the concept of sustainable development is addressed in line with REDD/REDD + schemes, followed by detailed background information about Sierra Leone as a nation [including the geography. Pre and Post-colonial management of forests, and political economy dimension]. Secondly, there is a focus on the concept of PES, and backed by ways of financing it, particularly in the context of Sierra Leone. Thirdly, there is discussion surrounding the case for PES, challenges and associated benefits. Lastly, the document concludes with an overview of the study and recommendations to address the situation in the context of Sierra Leone.
\end{abstract}

KEY WORDS: Sustainable Development, Alleviating Livelihoods, Financing, Sierra Leone

\section{INTRODUCTION}

The term sustainable development is a common phenomenon used in modern day society to encompass developmental approaches used in meeting the present needs of society, while at the same time maintaining a balance for future generations. According to the Centre for Environment Education (2007), the concept is designed to "maintain a balance between human need to improve lifestyle and feeling of well-being on one hand, and the preservation of the natural resources and ecosystems on which present and future generations depend. The concept historically emerged from a concerted effort designed by the United Nations in 1992; a reaffirmation of its conference on the Human Environment held in Stockholm, Sweden (5th - 16th June, 1972) to address a new goal and equitable partnership between states, and key sectors of society to protect the global environment and developmental systems (United Nations, 1992).

A successful sustainable development approach, whether instituted by a national government or a cooperative venture between international organisations, will always come at a cost, and hence those in it must ensure effective management and transparency is maintained by those on which funds are to be entrusted (for example the UN, World Bank and the IMF). As addressed by Najam (2002), the simplest way of escaping complexities of the efficient management of sustainable funds is through the establishment of NGOs, currently channelled through the UN REDD+ schemes and other on-going sustainable development projects. To say the least, it is not a $100 \%$ proof that funding of sustainable development projects through the works of NGOs can meet the desired objectives of reaching out to the neediest people / affected communities if parameters on its effective management are not well addressed in advance of implementation.

The central tenet of this document is therefore, based around well planned financial sustainable approaches, aimed at supporting forest dependent communities to access funds, which in turn may serve as a way of scaling down long term destruction caused through the degradation of forest reserves, and hence, the likelihood of high risks posed to the environment through increased rate of carbon emission on the earth surfaces and many more. Forest ecosystems particularly in developing nations around Africa, parts of Southeast Asia and South America, are the most highly affected when it comes to destruction caused to the environment. This is due in part, to high dependence on forest resources (e.g., Timber and Non-timber products) by poor community residents as their main source of livelihoods.

\section{BACKGROUND OF SIERRA LEONE AND ITS FOREST: AN OVERVIEW}

Sierra Leone as a country was established by an English humanist, Granville Sharp, to "repatriate" former slaves; a multi-ethnic and multi-linguistic groups of people, together created a new set of social and ethnic dynamics in the capital city (a derivative of Freedom), now popularly known as the Krios (July, 1970 and OECD, 2010). Sierra Leone as a nation consists of 149 constituent chiefdom established in 1986, under the premiership of Governor Cardew who empowered a set of 
Paramount Chiefs' ${ }^{11}$ as the sole authority of local government in the newly created Protectorate in Sierra Leone, which is the colony of 'Freetown' - the only recognised chieftaincy system of governance until 2004, when the World Bank donated funds resulting in the establishment of a local council systems (Reed and Robinson, 2013: 2). Prior to independence in 1961, the colony of Freetown was governed by an elected local government under the British legal system, while the rest of the country (registered as Protectorate) continued to be governed under the chieftaincy system of governance (OECD, 2010). The legacy of the divided country (Protectorate and the newly created Colony of Freetown) is still resonating in the entire structure of governance; this created heightened levels of ethnic tension and uptil recently, an untameable level of corruption demonstrated across the country (Jackson and Jabbie, 2020).

The first election for an administrative governance in the entire country was held in 1962, which also left the country divided on ethnic grounds, with series of coup plots (all in the late 1960s to 1980s) during the premiership of the 'All People's Party (APC) ${ }^{2}$, headed by the late Dr. Siaka P. Stevens and later in the 1980s, the transfer of power to the late Brigadier Joseph Saidu Momoh (OECD, 2010) - the emergence of the National Provisional Ruling Council (NPRC) made their presence in governance during the brutal ravaging of the country's economic system by the insurgence 'Revolutionary United Front (RUF) ${ }^{3}$ ], which then finally spearheaded the transition to a properly elected system of democratic governance after a legacy of brutalised tenure of governance in the country (Truth and Reconciliation Commission, 2004 and Suma, 2009.

\section{LANDSCAPING CHARACTERISTICS}

This is an important area in the pursuit of understanding the dynamics of the politics and forest management process in Sierra Leone, where an estimated $39 \%$ of the country is thought to be covered with forest, scattered in different location across the country, but more heavily in the eastern region and around Western Area Peninsula Forest (WAPFoR) territory (USAID, $\mathrm{n} / \mathrm{d})$.

\subsection{Location}

Sierra Leone is a small country located along the west coast of the African continent, and as descriptively outlined by Konteh (1997) and UNEP (2010), "it lies between latitude 6 degrees, 55 minutes and 10 degrees north, and longitudes 10 degrees and 13 degrees west. With a total area of 72,326 sq. km (27,699 sq. miles), it is compacted with approximately $346 \mathrm{~km}$ from north to south, and from east to west. The country is bordered to the southwest by the Atlantic Ocean, and with Liberia to the south-

\footnotetext{
1 According to Reed and Robinson (ibid), "Only individuals from the designated "ruling families" of a chieftaincy, the aristocracy created and given exclusive right to rule by the British at the initiation of the system in 1896, are eligible to become Paramount Chiefs".

${ }^{2}$ During the tenure of the authoritarian APC rule (in the 1960s 80 s), the country experienced high level of problems which caused great damage to the economic, effective governance, civil society and environmental (both land and marine based) fabrics of the country; between 1990 - 2000, the economy
}

east and Guinea on the north and northeast (Figure 1) - there are four provincial towns namely, North, South, East and West (WAPFoR), and 14 administrative districts".

\subsection{The Country's Geography}

The country is made up of four geographical zones (UNEP, 2010): "the interior plateau (generally flat and makes up approximately $40 \%$ of the country's surface, extended from north to south, and scattered with mountains mainly in the north and Eastern parts of the country), lowland plains (bordered with plateaus running down to the coastline, which makes up $43 \%$ of the country's area), coastlines (sloping and extends over 400 $\mathrm{km}$, comprising of mangrove swamps, beaches, terraces and ridges), and mountains (generally WAPFoR interspersed with forested hills)".

\subsection{Climate}

The country's climate is generally humid with two distinct seasons - "rainy and dry; the rainy season runs from May to October (rainfall generally varies, and relatively drier in the north and northeast region, approximately 2,500-3,000 millimetres per year to the southeast and 5,000 millimetres per year in the Western Area Peninsula). The dry season lasts from April to November, with varied degrees of dryness and interspersed with the Harmattan - daytime temperatures range from 25 to 34 degrees Celsius, temperatures generally drop as low as 16 degrees Celsius during the Harmattan. There are two types of climatic zones in Sierra Leone, with most of the country classified as 'tropical monsoon' and a thin belt of 'tropical savannah' along the northern border with Guinea. (Konteh, 1997 and UNEP, 2010)". PAPER SIZE: A4 size (210x297mm).

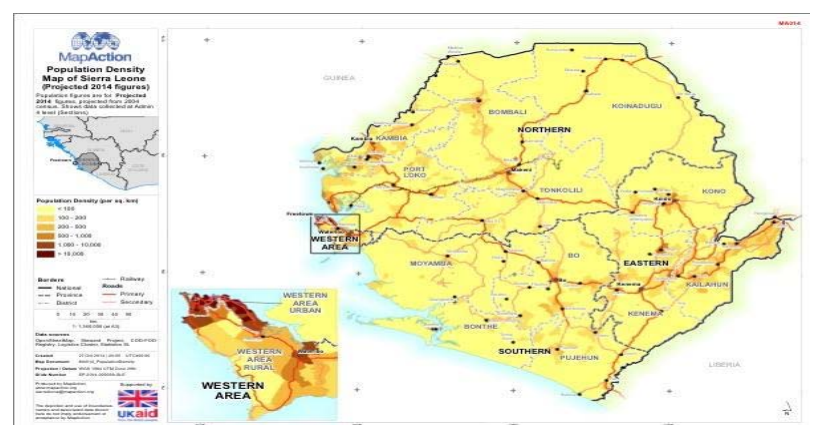

Figure 1: Map Showing Population Density of Sierra Leone (2014 Projection since October 2014)

Source: ReliefWeb International

contracted at an average of $4.5 \%$ annually, with a two-fold increase population growth to nearly 6 million (UNEP, 2010: $11)$.

${ }^{3}$ The RUF is a forced and disgruntled group of Sierra Leonean group of guerillas (headed by Fodau Sankoh, but received financial backing by Charles Taylor, the Liberian rebel leader) who had no respect for humanity, but with an intent on destroying the entire structure of the country's system, which is still impacting on the slow pace of development the country is struggling with (Suma, 2009). 


\section{POPULATION CHARACTERISTICS AND VITAL STATISTICS}

The population of Sierra Leone as illustrated in Figure 3 is approximately 6 million, according to the 2008 census statistics. The rural population is almost twice as higher than the urban population, which is reflected in the limited opportunity available to people in accessing jobs, and the high dependence of people in rural communities on natural and forest resources for their livelihoods. The approximate $70 \%$ poverty data is indicative of multiplicity of issues associated with low educational attainment that limit people's access to competing for high flying jobs. More specific to current day Sierra Leone, the legacy of a brutal civil war that infiltrated into the entire fabrics of the system (social, economic and environmental), also gave rise to forest communities targeted as one source of exploitation to fund guerilla activities (UNEP, 2010).

\begin{tabular}{|l|l|}
\hline Population & $\sim 6$ million \\
\hline Urban / Rural & $30-40$ percent $60-70$ percent \\
\hline GNI per capita & USD 666 (PPP) \\
\hline Acute poverty & $>70$ percent \\
\hline Inequality & Richest 20 percent does $>63$ percent of spending \\
\hline Human Development Index & 0.336 \\
\hline Ranked & $179 / 179$ \\
\hline $\begin{array}{l}\text { Source: UNEP, 2010 } \\
\text { Originally available from "CERI Program for Peace \& Hunnan Security. (2006, 2 June). Integrated approaches to } \\
\text { peacebuiding:A round-table discussion Sciences Po. Paris. } \\
\text { hutp://www.peacecenter.sciences-po.fripb-cr-home.hrmHobjectives". }\end{array}$ \\
\hline
\end{tabular}

Figure 2: Sierra Leone Vital Statistics

There is a high level of inequality in the country, with the poor still finding it hard to cope with basic livelihood requirements, while reliance on foreign aid is seen as a means to an end in funding essential activities by the government (IMF, 2009). Ranked at the bottom of the country profile table, the human development index is 0.336 , which is quite low given the natural resource potential of the country.

\section{POLITICAL ECONOMY OF FOREST POLICY IN SIERRA LEONE}

Forest is undoubtedly playing a great value in Sierra Leone's communities, and according to Alieu (2001), about $80 \%$ of the population is rural communities consume 6.2 million $\mathrm{m} 3$ of firewood; 396,000 m3 wood equivalent of charcoal; 43,200 m3 of fence sticks and $252,000 \mathrm{~m} 3$ of timber for construction, cooking, heating etc, per year. In western Sierra Leone alone particularly in the Freetown peninsular, it has been noted that over 70 plant species have been identified for plant medicine and dye, while the cabbage of the young palm tree, bush Yams [Discorea] are also important hungry season food for local residents (Jackson, 2015b; Mula and Saxena, 2010 and Alieu, 2001).

It is also noted that "during the next 2 decades, the area of legally constituted forest estates will continue to decrease due to urban and agricultural expansion, which will permanently change land use; about $10 \%$ of the country's land area [both government controlled estate and salvage] comprising of closed forests will be deforested at the rate of about $1.5-2.0 \%$ per annum, thereby increasing the area under forest re-growth currently occupying $60 \%$ of the country's total land area" (Alieu, 2001). This has given rise to direct impact on livelihoods, particularly for poor rural residents in forest communities around the WAPFoR covering Goderich-Tokeh (Jackson, 2015 b). The escalated scale of depleted forest caused by massive urbanisation and settlement in the Freetown peninsula is creating serious impact on survival of local residents, and also their social well-being and cultural ways of living which include hunting, rituals performed by traditional societies and medicinal capacity of the natural forest plantation (Jackson, 2015c and DeenSwarray, et al., 2013).

The management of forest ecosystems has been a topical discourse as early as in the colonial era (under the British control), while the continued scale of deforestation and forest degradation remains a highly political issue. With forest considered one of the main source of livelihoods for rural residents, it is apparent as to why people have developed some form of defiance on policies concerning the protection and conservation of forest areas (Wardell and Lund, 2006; Mvondo and Oyono, 2004; Davies, 2005; Munro \& Horst, 2011 and Jackson, 2015c). A widely supported view of Eurocentric Malthusian theory of population by policy makers in developing nations of Latin America, Southeast Asia and Africa (Sierra Leone not being an exception) has made things more difficult in terms of the conflicting views of policy makers to protect the environment (through activities like deforestation) on one hand, and that of rural community residents' whose main focus is geared towards securing avenues for a sustainable means of livelihood (Leach and Fairhead, 1994 \& 1995). In view of Munro and Horst (2011) study on the political ecology of forest policy in Sierra Leone (also in Leach and Fairhead, ibid; and Akiwumi 2006a \& 2006b), an examination of 19th century lumber exports clearly show that poor accountability in record keeping and also high level of smuggling, could be some of the contributing factors of the dwindling state of forests as opposed to the acclaimed assertion of over-exploitation by rural community residents and others far afield.

Even the establishment of forestry department across the African region, and particularly in Sierra Leone after the 'scramble for AFRICA' in the 1890 s was seen as a means of protecting the environment from exploitative usage (as manifested in legislative policies related to forest laws), its authenticity is still being criticize by scholars as a mere means of fooling the international community; an easy approach to the exportation of forest timber products to western economies, particularly in Europe (more so the UK as in the case with shipments from Sierra Leone), in achievement of their adventured dreams of profitability (in the case with corporations), and the balancing out of national accounting for the benefit of the state (Munro and Horst, 2011; Becker, 2001 and Meredith, 1986 and Lane-Poole, 2009). An established researcher in the area of forestry studies was able to confirm his investigation in relation to the UK government's establishment of the legal arm of the forestry department, which is seen as purely a means of reinforcing their hegemony, which is an easy means of exploiting the natural 
resource endowment of the country. Local means of use of the forest (more so in pursuit of livelihoods) was discouraged, but with laws favouring the active promotion of European style exportation of timber produce (particularly after the establishment of the Saw-Mill factory, see Munro, 2009, with original citations in Lane-Poole 1911; Unwin 1909) into their commercial markets. An excerpt quotation from Munro and Horst (2011), also cited in Alldridge (1910) outline an overt statement by a British Government's Travelling Commissioner in Sierra Leone during that time as illustrated thus: "Of course where Nature has been so lavish the natives are content with what they find to hand; it needs European intelligence to see what further wealth could be produced by cultivation, and to discover the uses to which the cultivated article could be applied, as well as a knowledge of the markets in which it could be sold".

The political economy of forest management in present day Sierra Leone needs thorough review, with clear focus in incorporating the complex dynamics of culture / traditions, and the prevailing global dynamics so as to make it worthwhile for the entire forest ecosystems to serve its beneficial purposes of livelihoods ${ }^{4}$, and the conservation of the environment through loss of high level of carbon emissions and climate change impacts. As identified by Jackson (2015d), even though nationals and more so high profile government officials have all been engaged in the deliberate exploitation of forest resource in Sierra Leone (through timber trade), it is quite clear that [in support of Alldridge's (ibid) criticism of Eurocentric approach on forest policy formulation] policies, for example, FLEGT implementation is not favourably monitored to expose culprits, but more to the advantage of multinational corporations in developed economies, thereby leaving nationals and rural residents in particular at the fringe of being disadvantaged with little or no chance(s) of gaining easy means of access to their local forests in pursuit of livelihoods.

In the case with Sierra Leone, forest is utilised by different groups (ethnic) for varied purposes; majority of the time, in pursuit of meeting livelihood needs - at the same time, the insurgence of RUF incursion (involving the recruitment of child soldiers) into the Sierra Leone territory shows how complex the politics of forest management can be, with its varied resources targeted by some as a way of finding easy means of paying for a senseless cause (Kaimowitz 2003 and USAID, n/d).

\section{COLONIAL AND POST-COLONIAL FOREST MANAGEMENT STRATEGIES}

The management of forest in Sierra Leone is considered a historic process, which includes the colonial and colonial eras. The colonial era is the period of time when the country was under the jurisdiction of the British (UK) government and every aspect of forest use was being determined by approval of HM Royal. Following this period, that is post-independence (1961), all activities in the country were managed by constitutional

\footnotetext{
${ }^{4}$ Frst and foremost, meeting the needs of rural residents, and as a secondary means for commercial purpose, but which may also
}

authorities in Sierra Leone, under the direction of the Forestry ministry.

\subsection{Colonial Forest Management}

Colonialism in Sierra Leone (under the British rule) commenced in 1808, at the time when the enclave Freetown became a 'Crown Colony' - prior to that, in 1778, it was used by a group of British philanthropist (also referred to as the Clapham Sect) to establish settlement for freed slaves (Dorward, 1981).

During the colonial era, various laws were enacted by the then authorities around 1808-1912 (the earlier part which was the pronouncement of the crown colony). Prior to this period, Sierra Leone had no laws governing the use / access to forests; the first of such move was done in 1911 with the appointment of Lane Poole to look into the extent of deforestation (which he blamed on recklessness of local people through deliberate acts of shifting cultivation), and for which such laws was a way of curbing the purported accusations (Konteh, 1997; Ribot and Cline-Cole, 1997). According to MacGregor (1942), cited in Konteh (ibid) the exploitation of the country's forests for timber trading was not documented in Lane's report which was very well embellished with an account of $99 \%$ loss to the Sierra Leone's rainforest being depleted, when in fact the exploitation had been an on-going as early as in 1816 around the Bullom Shores, Great Scarcies and Portloko by well-known British entrepreneur by the name of John McCormack.

Forestry activity in the colony was very active with the emergence of the Europeans, particularly the British, in the Sierra Leone territory who saw it as an easy way of enforcing their hegemony through the enactment of legal proceedings which prohibited people from relying on rich forest resources (for their livelihoods) - this was stampeded with the establishment of the Forestry department, and also the enactment of the country's first ever forest laws in 1912 (Cole, 1968; Leach and Fairhead, 2000; Munro, 2009, also cited in FD/SL, 1913). In January 1922, the Agriculture department was amalgamated with forestry as the two were thought as being too closely related in their activities, but most importantly, in a bid to reduce costs on the then colonial leadership in Sierra Leone after the loss of revenue from natural produce (particularly from forestry and agriculture) after the harsh impact felt from the World War 1 (Dorward, 1982). The legacy of a divided country, with a colony (now Western Area including WAPFoR), and the protectorate is still resonating in the collapsed state and mismanagement of the natural resource sector in Sierra Leone.

\subsection{Post-colonial Forest Management Strategies}

Post-colonial era marked the period after independence in 1961, which then saw more enforcement of protected areas of forest reserves (see Figure 4 below). The protection of forest land in the country is under the direction of the Forestry division at the Ministry of Agriculture, Forestry and Food Security (MAFFS), and more lately, the support of allied organisations like the help in providing some form of access to livelihood assets for the benefit of locals 
Environmental Protection Agency (EPA) and the National Protected Area Authority (NPAA) (Jackson, 2015a).

According to Alieu (online - n/d), the mandate of the forest department is to 'promote sustainable forest management through the concept of "wise use" of the country's natural resources'. The sustainable forest management phrase is use in this context as a means or measure, example will incorporate institutionalise legislations, and in some cases, physical protection to deter access $£$ set in place to assist with the preservation of forest locations so as to ensure it meets the livelihood needs of those who rely on it for their daily means of survival without destroying the ecosystems. In order to promote the division's goal of managing the forest ecosystems effectively, there has been a move taken towards decentralisation (which is consistent with the decentralisation act 2004), which has brought about breakdown into four branches, namely, Wildlife Conservation, Forest Conservation Research Branch (silviculture), and the privatised Rubber development (Alieu, ibid).

Equally, the establishment of legislative measures, at different point in time on the country's forest management goal is making an impact, and according to Jackson (2015a), these include the following:

- WildLife Conservation Acts, 1972: Since independence in 1961, Sierra Leone has struggled in her capacity to manage its natural resources, due to lack of a sustainable protection policy. According to IUCN (1993), the act identifies six protected area categories, namely 'National Park, Strict Nature Reserve, Game Reserve, Game Sanctuary, Controlled Hunting Area and Non-hunting Forest reserves'.

- Forestry Act (June1988): This gives MAFFS, and in particular the Forestry division the power to protect and conserve water, soil, flora and fauna. This prohibits activities dealing with the falling of trees and also granting of restricted license by the director of conservation to remove a protected tree (USAID, 2007). This act provided an opportunity for the then forestry ministry to establish room for the protection of valuable forest area, and most importantly, the reforestation of land which were considered to have gone through considerable exploitation / degradation. Within the legal provision of the act, it was forbidden for people or institutions to cut or even burn trees found within defined locations of what is typically classified as forest, except with the permission from the Chief Conservator of forest, on whose permission licenses were authorised. This act despite been considered as a step forward, it was poorly applied in practice, more so, due to poor monitoring by officials from the forest division at MAFFS, which then lead to one of the highest level of illegal access, particularly in the air-marked protected areas (Konteh, 1997, also cited in GOSL, 1989).

- National Biodiversity Strategy and Action Plan (NBSAP, 2003): This was prepared as an obligation to meet the UN convention on Biological Diversity. It is a safeguard measure to both terrestrial and aquatic biodiversity aimed at providing a firm framework for the benefit of present and future generations'. The NBSAP is also an advancement in the move to protecting biodiversity loss and the prevention of forest degradation.

- The Environment Protection Act 2000 and the Environmental Protection Agency (EPA) Act 2008: both of these acts were geared towards the protection of the environment, and which include the forest ecosystems. The EPA Act 2008 was more enforceable as it allowed the agency to procedure perpetrators who were wilfully working against the law, particularly working towards the destruction of the environment, which in effect would impact on livelihoods and the demise of biodiversity.

In addition to the above mentioned acts, officials and professionals on behalf of the government have taken a step forward by adding new draft laws, which is the 'Conservation and wildlife Policy and Forests Policy Acts (Brown and Crawford, 2012); this "sets out five principles which include species management, conservation areas, research and monitoring, education and awareness and capacity building (Jackson, 2015a). A late emergence on the drive to securely manage the sustainability of the forest ecosystems in Sierra Leone is the 'National Protection Area Authority and the Conservation Trust Fund (NPAA) Act 2012. This is also an arm of MAFFS, with the mandate of managing all areas dealing with the improvement of the environment, and more so, ensuring protected areas are effectively managed from deliberate abuse by the public (Jackson, 2015b).

In as much as the criticism raised about colonial hegemonic act of domination in controlling Sierra Leone's natural resources (particularly the forest sector, to name a few, easy timber export), attitudes of nationals, and more so the brutal rebel war that ravaged the economy, has exacerbate the dwindling state of forest reserve in the country to its current patchy state (Munro, 2009, an original citation in Baker et al. 2003). 


\begin{tabular}{|c|c|c|c|c|}
\hline Frocected aren & $3 \operatorname{cotan}$ & Sire (h) & District & Description \\
\hline Outumba Kilini & National Park & 110,501 & Bombuli & 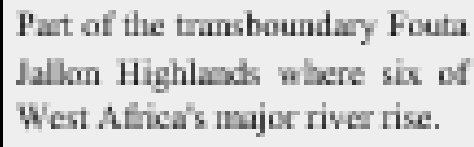 \\
\hline Goal Rainforest & National Park & 7,107 & $\begin{array}{l}\text { Kailshum, } \quad \text { Kesen, } \\
\text { Pujehum }\end{array}$ & $\begin{array}{l}\text { The last significunt puich of } \\
\text { cloced camopy rainforest in } \\
\text { Siena Lane. }\end{array}$ \\
\hline $\begin{array}{l}\text { Wertem Area } \\
\text { Peannula Forst }\end{array}$ & $\begin{array}{l}\text { Non-Hunting } \\
\text { resere }\end{array}$ & 17,08 & Weilon Ama & $\begin{array}{l}\text { Forest on the hills outside } \\
\text { Freciown which ponids mosh } \\
\text { of the capitals fres wake } \\
\text { supply. }\end{array}$ \\
\hline Lima Mountains & $\begin{array}{l}\text { Non-Hunting } \\
\text { resere }\end{array}$ & 34,501 & Koinadugu & 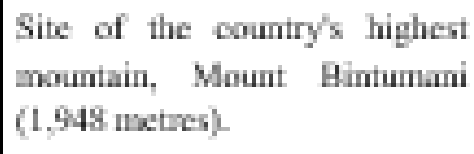 \\
\hline Kangmi Hills & $\begin{array}{l}\text { Non-Hunting } \\
\text { reserve }\end{array}$ & 8,53 & Bo, Tankoliti & 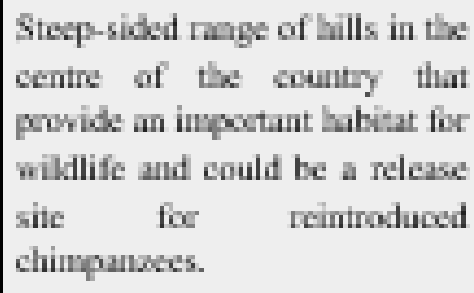 \\
\hline Tingi Hills & $\begin{array}{l}\text { Non-Hunting } \\
\text { reserve }\end{array}$ & 10,54 & Koinuduge, Kons & $\begin{array}{l}\text { Remoit ane of North-eastem } \\
\text { Siern Lene renowned for its } \\
\text { butholiths. }\end{array}$ \\
\hline Tisai Island & $\begin{array}{l}\text { Wildite } \\
\text { sulctury } \\
\text { commsinity } \\
\text { conservancy. }\end{array}$ & 1200 & Pujdhun, Kenema & 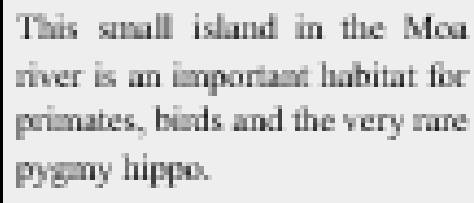 \\
\hline Kambui Hills & Forst Bewere & 21288 & Kenen & $\begin{array}{l}\text { Forest on low-lying range of } \\
\text { hills west of Kenema which is } \\
\text { threatesed by longing and } \\
\text { nining. }\end{array}$ \\
\hline $\begin{array}{l}\text { Siena Leole River } \\
\text { Ftuay }\end{array}$ & Aanum sise & 295,001 & Part Laka, Werter Ara & $\begin{array}{l}\text { The country anly Bumsin site, } \\
\text { and wi weh the only marine are } \\
\text { afforded any level of potection. }\end{array}$ \\
\hline
\end{tabular}

Figure 3: Protected Area

Source: World Bank 2006 (also cited in Jackson, 2015a)

\section{WARS AS DRIVERS OF FAILED FOREST POLICY IN SIERRA LEONE}

According to Beevers, 2012 (also cited in de Jong, Donovan, and Abe, 2007; UNRP, 2010), there is strong correlation indicating that nearly half of conflicts in the 20th century are linked with forested regions, mostly in tropical countries. Perspectives from scholars like Homer-Dixon (1991) and Kaplan (1994), testify the fact that forest degradation and high population growth, backed by poor forest management (particularly in poor tropical rich forest economies) have intensified violent tendencies towards people's innate ability to protect territories associated 
with their livelihood space. Scholars like Ross (2003) have also subscribed to the fact that countries endowed with natural resources have higher tendencies for people to engage in conflicts as it is purported to be a base for people to enhance their livelihoods through easy access to a variety of resources, which can transform their lives.

Sierra Leone is a small country with a population of just about 6 million (based previous statistics figure 3), and endowed with valuable land/based natural resources (such as diamonds, rutile and timber based products like rubber and pole) - evidence revealed that the rich attraction of these resources is an influencing factor for the prolonged fighting which Sierra Leone experienced for nearly a decade, between 1991 - 2001 (Munro, 2009; UNEP, 2010). According to Beevers. 2012 (also strongly cited in Reno 1998: 2000), evidence also points to the fact that exclusive dependence on timber income (particularly in tropical under-developed economies) is likely to create weak state governance due to high possibility of corruption, and a possible incitement for violence - the case of Al Jazeera's under-cover investigation about high profile corruption in timber trade in Sierra Leone is also a testament of this situation (Jackson, 2015d; Jackson, 2016).

\section{SUSTAINABLE LIVELIHOOD AND FOREST MANAGEMENT NEXUS IN SIERRA LEONE}

Shahbaz and Suleri (2009) highlighted two overarching issues based on contemporary literature about the linkages between rural livelihood security and forest management; and these include:

- How and to what extent forest resources can contribute to poverty alleviation.

- How and to what extent poverty alleviation and forest conservation can be made convergent rather than divergent goals".

Forest-based resources play a very important role in the lives of poor rural communities in Sierra Leone, more so given the fact that poverty is an endemic thing in the country. Current legislations in relation to access to forest in the country is posing serious problems in terms of the sustainable livelihoods of people, for example, legislative measure such as those stipulated according to the forest laws of Sierra Leone (Forest Acts 1988 and more lately the NPAA) means that people, particularly those in rural communities are more or less prevented from gaining access to seek basic livelihood needs.

Policies relating to land (particularly in forested areas such as WAPFoR) have witnessed great tension between the Ministry of Lands and MAFFS, and these in effect seemed to have threatened livelihoods for nearby forest community dwellers in terms of their sustained livelihoods - in some cases, officials

\footnotetext{
${ }^{5}$ Forest and agriculture divisions at MAFFS, international and local organisations, civil society and local community groups.
}

have been directly involved in the selling of lands (Munro, 2009).

In a bid to meeting the sustainable livelihood target, successive governments through the administrative arm (MAFFS), have been working hard since 2008 at restructuring the forestry division to incorporate the $3 \mathrm{C}$ model (Figure 6), namely 'Commercial Forestry, Conservation \& Wildlife Management and Community Forestry', headed by an Assistant Director of Forestry as shown below in Figure (Amazon Web Services, n/d). In order to move on with the government mission of meeting its priority in protecting the forest ecosystems, and in addition addressing the livelihood and poverty state of forest community dependents, a national workshop was convened in the early part of the year 2009 (precisely 3rd - 5th February) and backed by international organisations and NGOs like the European Union (EU) and the United States Agency for International Development (USAID) to review existing policies, laws and regulations of forestry division in the country as a whole - the outcome of this resulted in the formation of an Advisory Committee (AC) incorporating representatives from various groups $^{5}$, with the ultimate goal of achieving two policies to address 'forestry and wildlife conservation' (Amazon Web Service, $\mathrm{n} / \mathrm{d}$ ). The positive thing about the consultation was the efforts geared towards engaging the wider public (through national broadcast in the most widely spoken vernacular, Krio to keep people informed about the AC's decision, and it is the expectation that the outcome of the consultation would address parts of the constitution of Sierra Leone as outlined below, an excerpt from Amazon Web Service (n/d):

[Section 7(1)a], which is simply the "harnessing all the natural resources of the nation to promote national prosperity and an efficient, dynamic and self-reliant economy"

[Section 11.3.2)], geared towards the reduction of forest degradation and the conservation of biodiversity and this specifically is also in support of the "Sierra Leone Poverty Reduction Strategy II, "Agenda for Change" (PRS II), which identifies poverty alleviation and environmental management nexuses.

[Section 11.4], part of that PRS11 obligation to address the sustainable management of forest resources in reducing poverty through the encouragement of activities like Ecotourism, community forest management, and the commercialization of forestland (involving activities like lawful timber trading which is in line with the international FLEGT standards).

The above expression in supporting the effective management of forest to promote sustainable living seemed good on paper, but how far does it go in terms of addressing the livelihood needs of poor people in Sierra Leone is critically contentious. As already addressed in earlier section, the country is highly divided on the basis of the division created in the country by the colonial power (Munro, 2008: 2009), and which makes it very difficult for poor people (particularly rural and indigenous forest 
community residents) across the country to fully harness resources to meet their daily livelihood needs - heavily focus on the commercialization of forest lands have seen the exploitation of timber products by both high profile nationals through connivance with international corporations to exploit the country's rich national environment, while the environment is left in destructive tatters and those community dependent left to struggle for their daily survival (Jackson 2015d; Jackson, 2016 and Munro, 2009). It is no surprise in the country to have seen an upsurge in the rate and escalation of what gave rise to the 10year brutal civil crisis and for forest lands across the country were seen as easy target for rebel fighters to target because of their endowed assets which were sold to purchase arms (UNEP, 2010).

This brings one closer in addressing Shahbaz and Suleri's (2009) concerns / issues (how and to what extent poverty alleviation and forest conservation can be made convergent rather than divergent goals) ${ }^{6}$. As in the case with Sierra Leone where poverty is rather high, access to forest by locals is seriously threatened, while at the same time ensuring that their usage is done in a sustainable way to ensure the forest ecosystems is effectively managed without much of a destruction to existing biodiversity. This required properly trained and qualified personnel (from the forest division at MAFFS) and supported by other national groups to help address the ongoing problems of forest loss and risks to the sustainability of livelihoods from forest resources.

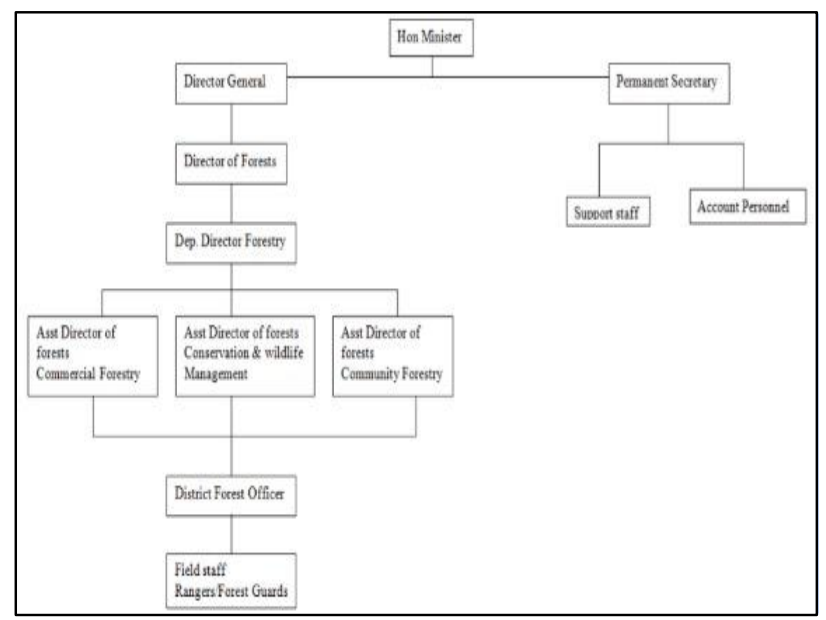

Figure 4: The $3 \mathrm{C}^{\prime}$ 's Administrative Structure at MAFFS Source: Amazon Web Services

\section{PAYMENT FOR ECOSYSTEMS SERVICES (PES): APPROACH TO SUSTAINABLE FOREST MANAGEMENT (SFM) IN SIERRA LEONE}

Having looked at the situation of sustainable livelihood and forest management nexus in Sierra Leone, it is now appropriate to explore critically, approaches used in the country (much more supported by international organisations and the national government) to finance livelihood sustainability in addressing long term protection / conservation of the forest ecosystems.

Sierra Leone, though small in size, is well endowed in natural forest resources, this over the years has helped to sustain lives, particularly poor community residents close to forest locations. The extent of depletion of its forest (prominent during the 10years brutal civil war) had led to the adoption of proactive actions (legislative) resulting in the establishment of organisations like the EPA in 2008 and NPAA in 2014. Legislative measures on its own cannot work effectively in a country like Sierra Leone where rural poverty is at an escalation rate, and so incentive schemes aimed at encouraging forest users to make productive use of forest areas is something that started making its way in the development agenda in the late 1980s, through popular supported schemes such as PES from international organisations like the United Nations (UN) and the International Monetary Fund (IMF), intended to encourage forest users to make productive use of their natural habitation.

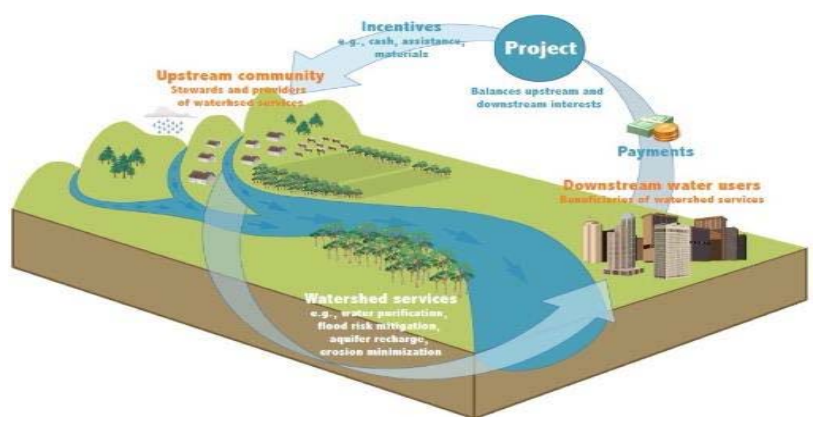

Figure 5: PES Diagram

Source: A Best Practice Guide (Department for Environment, Food and Rural Affairs)

Figure 7 provides an illustration of a typical PES project undertaken by DEFRA to support productive use of forest land (referred in this situation as Upstream and Downstream),

legislative acts pertaining the protection of forest in Sierra Leone (more so the latest of which is the NPAA act 2013), there is hardly any substantive information dealing with the sustainable use of the forest environment that favours the protection of local residents (The World Law Guide, $\mathrm{n} / \mathrm{d}$ ). These are all meant to salvage the remains of the destructive environment rather than converging it with the livelihood needs.

\footnotetext{
${ }^{6}$ Current policy focus in Sierra Leone is heavily directed at the conservation of forest environment which is quite good, particularly in addressing environmental concerns, but the scope for sustainable livelihood is actually not consistent with the requirements of international standard; forest community residents are the most vulnerable when it comes to policy implementation relating to restricted forest usage. In view of
} 
through which incentives / payments are made (voluntary participation) for those in use of the service. Such a scheme comes with its benefits to users (particularly poor residents) in terms of direct cash, which support livelihood in a sustainable way, and much more supported mechanism of skills development, but to the nation at large, an improvement or a regeneration of the depleted environment which is more in support with global action on climate change mitigation (reference to Jackson 2015e).

\subsection{Types of PES and their use to Communities}

According to the DEFRA (2013), there are three broad categories of PES as outlined below:

- Public payment schemes through which the government pays land or resource managers to enhance ecosystem services on behalf of the wider public.

- Private payment schemes, self-organised private deals in which beneficiaries of ecosystem services contract directly with service providers.

- Public-Private payment schemes that draw on both government and private funds to pay land or other resource managers for the delivery of ecosystem services.

The adoption of any of the above PES scheme(s) can be done at different special scale (DEFRA, ibid), and for which conditionality are likely to be imposed so as to ensure the desired purpose of such payment (which is mostly geared towards mitigating hazards of the environment) is adhered to for the good of all. Generally, the range scale of PES scale would include all or mixture of the following, depending on the degree of sustainable funds available (DEFRA, ibid):

- International: examples include Reducing Emissions from Deforestation and Degradation (REDD+) whereby developing countries that are willing and able to reduce emissions from deforestation and degradation are paid by developed countries for doing so.

- National: for example the Environmental Stewardship programme, a government-financed scheme in which in the UK situation, about $£ 400$ million a year is paid to farmers and land managers on behalf of the public in return for more environmentally-sensitive farming.

- Catchment: for example, downstream water users paying for appropriate watershed management on upstream land. These schemes tend to be private-financed, for example where a water utility pays upland land managers on behalf of its customers to implement certain measures designed to stabilise or improve water quality.

- Local / neighbourhood: for example, a scheme whereby residents collectively fund a warden or environmental organisation to manage local green space for biodiversity, landscape and recreational value.

In the developing country context, and particularly in a countries like Sierra Leone, the REDD+ scheme seemed to be the most popular as funds provided seemed to be of at guaranteed level, in comparison to schemes managed at local or national level.

Developing economies in Africa, some parts of Asia and Latin America have suffered a lot when it comes to issue on degradation / depletion of the forest ecosystems. For poor rural residents, this is highly attributed to poverty, which meant that the quest to seek for sustainable livelihood signify people's ability to engage themselves in activities that are considered non-environmentally friendly. The motive behind the formation of PES is very good, but its implementation for poor nations like Sierra Leone can be very hard for poor rural residents given the stringent conditionality imposed. A robustly critical approach is needed to address the way forward in ensuring that corporate organisations using the forest ecosystems should be tied to actions taken in the establishment of funds to mitigate pressures faced by poor residents and the environment as a whole.

\subsection{What is PES and how is it addressed in the Sierra Leone Context}

Lately, Sierra Leone, through its link with popular schemed like the Kyoto Protocol commenced steps towards meeting international demands / calls for the preservation of its forest ecosystems; an example of such approach have been geared towards financial payment to forest community to minimise their over-usage of forest land, commonly referred to as 'Payment for Ecosystems Services (PES)'. According to the Department for Environment, Food and Rural Affairs (DEFRA, 2013), "the term PES is used to describe schemes in which the beneficiaries, or users, of ecosystem services provide payment to the stewards, or providers, of ecosystem services - in practice, PES often involves a series of payments to land or other natural resource managers in return for a guaranteed flow of ecosystem services (or, more commonly, for management actions likely to enhance their provision) over-and-above what would otherwise be provided in the absence of payment. Payments are made by the beneficiaries of the services in question, for example, individuals, communities, businesses or governments acting on behalf of various parties".

It is thought that such payments would help to divert users' attention away from clearing up thick / protected forest areas, but more so engaging themselves into more productive Agrobased activities like 'Agroforestry and community forestry'. Over and above, funds earmarked for PES can also serve as a means to enhancing community participation in improving the attractiveness of forest territories, more so for tourists, who in most cases may be charged for accessing services provided.

\subsection{Sources of Finance Scheme for PES}

This section provides the scope for addressing sources of finance schemes for PES in general, and specifically the case with Sierra Leone.

\subsubsection{Reducing Emission on Deforestation and Forest Degradation}

In 2013, Sierra Leone adopted the first of its formal PES scheme (REDD+), as a result of international pressure in ensuring people's livelihoods are well protected, while at the same time 
preserving a sustainable natural resource environment for the benefit of both present and future generations. Forest in the country has undergone huge losses as a result of encroachment into protected areas, and the effect of this is continuously felt on the environment (through land degradation), and also a direct impact on climate change vulnerability (Jackson, 2015b; IUCN,1993). More lately, the international cry in terms of raising alarm on the abuse of natural resources such as the overusage of 'forest land' has helped initiated new dimension on how best to protect the environment through UN sponsored activities like 'REDD / $\boldsymbol{R E D D + ' ; ~ t h i s ~ i s ~ g e a r e d ~ t o w a r d s ~ ' R e d u c i n g ~}$ Emission from Deforestation and Forest Degradation (REDD+). It is thought that through this, poor community residents will be able to address sustainable livelihood needs through payment schemes so as to divert the abuse of forest areas into more productive activities. This idea which started in 2008, is supported by the UNEP and Forest Investment Programme (FIP), and hosted by the World Bank, with funds been pledged by countries in the Scandinavian block and mainland Europe of which Spain committed an amount of US\$20.2 between 198999 , and with a commitment of an expansion to 40 countries between 2010-15 (Jackson, 2015; UNEP, 2010).

In Sierra Leone, this new dimension strategy was launched in July 2013 (with initial capacity building programme piloted earlier in May 2013) to assess compliance and readiness by officials to implement the scheme (Jackson, ibid). The REDD+ initiative was seen as a form compensatory scheme to support the rural poor in reducing their destructive acts of deforesting the environment, while at the same time enhancing their scope towards skills acquisition through community initiatives like community based forestry and agroforestry.

Steps towards the financing of ecosystems services, and more so the protection of livelihoods for the poor have been highly debated by the international communities, for example umbrella organisations within the United Nations (Food and Agricultural Organisation [FAO] and the United Nations Environment Program [UNEP] and World Bank (CIFOR, n/d and UNEP, 2010a). Funding for PES schemes, particularly in developing nations like Sierra Leones is heavily funded by international organisations like the current instituted UN REDD+ scheme (The Red desk, 2013). The scheme is meant to serve multiple purposes, more so in terms of protecting the environment from its current state of destruction, and also an improvement in sustainable agricultural productivity for those community rural dwellers whose lives are heavily dependent on forest resources for their daily livelihoods (FAO, 2013).

In Sierra Leone, emphasis of PES is on the REDD/REDD+ agenda which is geared towards the provision of accessible funds to forest community dwellers in order to minimise their over-usage of forests, and particularly protected area lands. According to a report from Ecosystem Marketplace (2015: 7), the call for such action was borne out of the Physicist Freeman Dyson's work in 1977 (Can We Control the Carbon Dioxide in the Atmosphere?) in a bid to alert the international community about the need to put a halt on the rise of $\mathrm{CO}_{2}$ in the atmosphere; in his conclusion, he suggested the planting of trees as a means of catching up with the already destructive state of the environment perpetrated by over usage of forest land in particular. Deforestation (accounting for about 20\% of greenhouse gas emission) is currently an area of great concern in Sierra Leone, and the introduction of REDD/REDD+, and more so with its financial grant scheme is supposedly meant to assist dependent communities to minimise their destructive actions to protected forests areas, which in the long-run will help in curbing threats to the vulnerability of climate change disasters already faced by the global community.

Management of the UN REDD/REDD+ scheme in Sierra Leone is done by the forestry division at the Ministry of Agriculture, Forestry and Food Security (MAFFS); the establishment of the National Protected Area Authority (NPAA), and more so the launching of its activities on the $28^{\text {th }}$ January 2016 is a step towards the government's initiative in meeting with the international call in combating high risk of climate change posed to the environment (Global Climate Change Alliance+ $[\mathrm{GCCA}+], \mathrm{n} / \mathrm{d})$. The decentralisation of institutional settings in Sierra Leone is making the hopes for achieving the UN REDD/REDD+ scheme a possibility; such scheme is supported by the Royal Society for the Protection of Birds (RSPB), and partnered Conservation Society of Sierra Leone (CSSL) as part of its activities in the Gola forest region, the Environmental Forum for Action (ENFORAC), and more recently, the NPAA which is a direct arm of the forest division at MAFFS.

As in the case with Sierra Leone, the true impact of such a scheme is yet to be felt / realised after the first four years of its inception window. The legacy of the divided land tenure system (Colony which incorporates the entire Western Area and the Protectorate) created by the colonial power (the then British government) is one of the first hurdles in determining carbon emission rights, and under which payments / credits can be claimed (Conway and O'Sullivan, 2011). The Environmental Protection Agency (EPA - guided by the EPA Acts 2008) is the institution responsible for ensuring safeguarding measures are adhered to through its monitoring of renewable resource usage (which includes forest), and hence meant that individuals and / or groups can be prohibited from converting land / forest into other purpose without the granting of proper license - in terms of the socio-economic safeguards, reference to the Constitution (1991: Section 8.3) stressed the importance of the natural forest environment as a valuable source for people's livelihoods, which means that draft policies and laws have to address livelihood impacts seriously, particularly those affecting lives of ordinary people, thereby restricting their access to secure sustained living (Conway and O'Sullivan, ibid).

There have been mixed messages about the true impact of the new dimension REDD+ initiatives across countries in Africa, Asia and Latin America where it had already been implemented. In some areas / countries where the scheme was intended to leverage the difficulty in terms of loss of earnings from forest, it has made life too difficult as funds were either not paid at the expected rate (due to high level of bureaucracy), and hence leaving people to struggle in meeting basic livelihood needs - it was even noteworthy that the $\$ 200,000$ initial grant expected 
from the 'Forest Carbon Partnership Facility (FCPF) Readiness Preparation Proposal (R-PP)' could not be accessed easily, and hence undermining the safeguarding measure (Creek and Nakhooda, 2011; Wong, 2014).

\subsubsection{Other Financing Schemes [Central Bank Corporate Responsibility Mandate]}

All around the world and more so in Asia and the Pacific regions, there is a call for stakeholders, particularly institutions like central banks to engage actively in sustainable development agendas that protect the environment from rapid depletion. This has taken the form of the provision of financial schemes to ensure the earth is sustainably managed through projects like Energy Security, Water and Food Security and Ecosystems and Biodiversity conservation (UN ESCAP, 2012). The state of forest in Sierra Leone is deteriorating at an alarming rate, and with reports indicating less than $5 \%$ of the country in a deplorable state of forest cover, exacerbated by the intensity in tree logging and more lately, the increase population around urban towns, particularly along the WAPFoR location (Government of Sierra Leone, 2010; Jackson, 2015a and Jackson, 2015b).

Prior to the civil crisis in Sierra Leone, the National Development Bank (a financial Intermediary, under the guidance of the Central Bank of Sierra Leone) was established as a way of promoting sustainable agricultural investment projects through financial / loan schemes provided by the bank to rural residents / potential investors in expanding agricultural projects in meeting livelihood needs, with the obvious benefits of improving employment prospects. The bank as it were, was $100 \%$ owned by the government of Sierra Leone, and for which development project activities funded by the international communities [e.g., the European Union, World Bank and IMF and the African Development Bank] were channelled through the bank, and with monitoring left in the hands of qualified banking staff to monitor operations. The hopes of such operations by the bank was blighted by emergence of the senseless civil crisis which saw sustainable investments in agricultural plantations being wrecked by the wicked acts of brutal rebels.

Lessons from other regions in the world, particularly in Asia and the Pacific, and also in some parts of the African Sub-region have witnessed tremendous benefits of individual Central Banks towards sustainable finance projects in alleviating conditions for the poor around rural areas in supporting the green economy (Ecosystem Marketplace, 2015 and Barkawi and Monnin, 2015). Such operations have included schemes like charges levied by the central bank on the operation of commercial banks and other corporations towards financing the green economy (Lipper, McCarthy, and Zilberman, 2009). Through such schemes, central banks in countries like Bangladesh (Barkawi and Monnin, 2015) have been able to raise funds that are used by the central bank in meeting its objectives towards sustainable development projects. These are normally given out in the form of low interest rates charged so as to make it possible for people or community groups to meet the cost of financing their debts, while at the same time meeting their livelihood commitments.

\subsubsection{Other Means of Financing}

Several schemes managed under the umbrella of PES are also directed and monitored by the Ministry of Finance and Economic Development [MOFED] in Sierra Leone. These normally come in the form of soft loans, in which interest rates on return for payment is normally made in small rates. Major parts of PES schemes are funded through agricultural developments in Sierra Leone. The CDC recent investment of over $£ 15$ Million on Miro Forestry operation in Sierra Leone is a wake-up call in support of the organisation's operation in the country; an approach geared towards sustainable investment in the natural resource sector, while acknowledging the potential of the human resource development in enhancing skills for community residents around the Yoni community (CDC, 2015). In welcoming notes, there was a positive response from both the then Minister of Finance and Economic Development [MOFED] and the Head of Miro Forestry in Sierra Leone [Andrew Collins]:

“Dr. Kaifala Marah, Sierra Leone's Minister of Finance and Economic Development - We welcome news of CDC's investment in our forestry sector. It comes at a time when the industry is faced with daunting challenges exacerbated by the Ebola crisis. We will work with Miro Forestry to harness mutual benefits from this venture in ways that will improve and expand our forests, boost job creation and contribute to our post-Ebola recovery efforts."

Andrew Collins, Miro Forestry - "We are delighted to have both CDC and Finnfund supporting the long-term development of the company. Both are experienced in the region in which we operate and together they provide us with significant support to ensure we attain highest financial, operational, social, environmental and ethical standards across the group. Sustainable plantation forestry is naturally a business that can provide competitive financial return, whilst significantly improving the long-term economic, social and environmental position of the rural areas in which we operate. Our focus remains to continue our stepwise growth, operating with thrift to ensure we remain economically competitive, with a high quality team and work standards, building long-term sustainable business of which all stakeholders can be proud." (CDC, 2015).

This is considered as a low form of interest financing aimed at improving the situation of sustainable investment in the natural resource sector, as well as raising prospects for job creation and a likely environmentally friendly community that addresses issues around climate change and carbon emission.

\section{BARRIERS / CHALLENGES TO ACCESSING SUSTAINABLE FINANCING}

As stated in the case with Miro Forestry, a thriving forest investment organisation, the situation of attracting financing is treated differently from that of an ordinary / rural community dweller in Sierra Leone who may also require similar support to help raise their scope for enhancing an environmentally friendly society. Rural community residents are more likely to experience difficulties in attracting funds, and such embargo normally comes as a result of their inability to be able to provide secure means of collateral, which may be seen as substitute in the event of a default in their loan agreements.

Funds provided through REDD/REDD + schemes are more easily accessible by poor community residents whose lives are 
heavily dependent on renewal forest resources for their livelihoods. On a similar note, there are also conditions imposed, which makes it quite difficult for forest users to access funds, particularly so in the short term. In this situation, livelihood for these community residents normally takes a down-turn as a result of the fact that their usage of the forest environment will be curtailed during the time of waiting for conditions to be assessed (Jackson, 2015a).

In Sierra Leone, Public initiated PES schemes [one in which government pays resource managers to enhance ecosystems services] can be the easy means to accessing funds, but are not adequately monitored as funds can either be too little or are not monitored adequately for those seeking financial support to improving their livelihoods, while at the same time protecting the environment. In the typical Private and Public-Private PES schemes, access to financing can be very hard to come by, particularly for poor rural residents who may not have the collateral support to help accessing funds. An example of Public-Private PES is that of the already UN REDD/REDD+ schemes, which are normally monitored by donor experts and supported by locals such as staff within local institutions like NPAA. As addressed by OECD (2012), the costs and capacity of supplying PES is heterogeneous, and hence it has come up as a recommendation that such a situation should be taken into consideration, with discriminate payment made in terms of factoring extraneous conditions for those needing to access the service.

As already mentioned in the case with Miro Forestry, the announcement of such payment is a typical case of high level discrimination simply on the basis of the organisation's potential to access collateral support, which is non-present with local community organisations or individuals in rural communities. Miro Forestry is considered a good sizeable multinational corporation, with almost middle income shareholders, and their ability to be able to demonstrate evidence of collaterals is quite easy and the ability to meet financial requirements as part of loan repayments can be easily met.

As in the case with local residents, the lack of adequate collaterals may sometimes undermine the illegal and unsustainable exploitation of the natural habitation. In such a case, local / rural residents who are quite familiar with the terrain of forest lands can easily exploit resources without or minimal punishment imposed. This is also an approach to increasing the environmental risk to climate change vulnerability as experienced in the current state of deforestation in Sierra Leone. Particularly with Sierra Leone, PES implementation is faced with some of the highlighted challenges (Government of Sierra Leone, 2010):

- No district/provincial and/or national level REDD carbon institutional framework/architecture in place (e.g. the NSCC, including the National Registry for REDD and non-REDD carbon);

- Some legislators (members of parliament) and unscrupulous international and local businessmen/businesses have already started crashing into the programme without the consent of government; thus posing a threat to national interest as the country could be disqualified for "double counting", lack of transparency/credibility and other defaulting factors;

- Absence of appropriate national level legislation for carbon (but this could be overlooked for the time being while capacity and experience are being acquired);

- Low awareness of REDD/PES potential at national, provincial, district and site levels (e.g. our legislators, top public servants, private sector leaders and others need to be enlightened on this subject);

- Ineffective tourism strategies to date and limited community involvement in ecotourism development;

- Significant need to strengthen capacities in financial budgeting, accounting, fiscal management and other aspects of financial governance - i.e. Financial monitoring, reporting and verification (F-MRV) capacity building as part of REDD readiness for effective management of REDD financial flows from Annex -1countries or the global climate change fund.

\section{BENEFITS AND THE CASE FOR PES IN ENHANCING SUSTAINABLE FOREST MANAGEMENT IN SIERRA LEONE}

This section is incorporated with the aim of addressing a special case for PES and its overarching benefits to communities, particularly those in rural areas, experiencing difficulties in accessing alternative means of support in minimising their abuse of forest resources. The high percentage of poverty in Sierra Leone, more so those in rural communities is making it very difficult for targets in relation to improving environmental services to be met at any point in time [Jackson, 2015a]. The deferred payment approach, which normally means that people are required to satisfy all requirements is proving risky to lives and more so for residents in rural communities in a country like Sierra Leone.

\subsection{Case for PES in Enhancing Sustainable Forest Management in Sierra Leone}

Sierra Leone has gone through bitter experiences, for example, more than a decade of civil crisis and other natural crises (Munro, 2009 and Jackson, 2015b). This has made it very difficult for the national government to plan developmental activities given the high population mobility in the capital city and peri-urban locations along the Western Area Peninsula Forest (WAPFoR) - resources such as land, incorporating the natural forest environment is at risk of being over utilised, thereby giving rise to biodiversity extinction in typical forest communities along the WAPFoR area (Jackson, 2015b and Jackson, 2015c). This means that those poor rural community residents are certainly at risk of being faced with the difficulty of accessing adequate resources to support their livelihood existence, thereby adding pressure on the natural forest reserve to end up being deforested and degraded (Jackson, 2021a).

The case for PES is highly warranted in this situation as a first step towards preserving the environment from the calamity of climate change disaster. People within local communities need to be supported through schemes like the current instituted REDD/REDD+ and where necessary, backed by other locally 
instituted programmes as considered necessary by institutions like the central bank and non-profit organisations. The REDD/REDD+ scheme comes with conditions attached to it, and experience from other countries around Africa, Asia and Latin American countries indicate varying experiences as part of the process of instituting the scheme (Lipper and Neves, 2011; and Engel and Palmer, 2009).

As a voluntary means of contractual agreement between the beneficiary of environmental services and land managers, it means that the adoption of scheme is theoretically contingent on the following:

\begin{abstract}
Additionality of PES investments: payments or in-kind contributions are only targeted at land managers that can deliver environmental benefits additional to a baseline or "business as usual" scenario;
\end{abstract}

Conditionality: payments are only released following appropriate verification of adoption and maintenance of the agreed practices; and

(iii) Permanence of interventions: a special important condition when dealing with regenerating ecosystem functions that requires extended time frames (Wunder 2005; GEF 2008; and Lipper and Neves, 2011).

The Monitoring, Verification and Reporting [MVR] of the scheme is highly dependent on the above three conditions being achieved. For poor rural forest dependent users / communities, PES implementation can be seen as difficult to achieve as emphasised by the FAO (2007).

Lessons learned from countries within the aforesaid mentioned regions [Asia, Latin America and Africa] will need to be dealt with sensitively, particularly given the situation with residents around forest communities whose bitter experiences with wars is making it difficult for them to find ways of accessing funds to maintain basic means of livelihood, which does not involve destroying the natural forest environment. As in the case with many developing nations, deforestation is one of the major cause of climate change issue facing the Sierra Leone economy (Alieu, 2001 and Alieu, $\mathrm{n} / \mathrm{d}$ ); overturning this will require soft, but more focused and monitored approach to appease the minds of residents whose livelihoods have always been highly dependent on forest renewable resources, for example, timber, firewood, and other edible food products.

One of the central tenets of a good PES implementation is to ensure sufficient safeguard measures are set in place to protect sustained livelihoods for local residents. This can be done by ensuring payments are made as quickly as possible, while at the same time ensuring forest environments are adequately managed for the good of present and future generations. Given the willingness of the Sierra Leone government (as reiterated by successive leaders), the country is in a good position to sail through the storm in ensuring PES is fully adopted.

\subsection{Benefits of PES in the Context of Sierra Leone}

Despite some of the highlight challenges / concerns about PES, there are obvious benefits; with reference to Sierra Leone, it is a worthwhile venture of investment given the long-standing difficulties the country has experienced in recent past; to name a few, nearly two decades of civil war, Ebola pandemic and now the global calamity of COVID-19 pandemic (Jackson, 2021b; Jackson, 2016). Based on the Government of Sierra Leone (2010) report, some of the benefits of adopting PES scheme are summarised as highlighted below:

- Significant amount of high carbon habitat: natural tropical high forest or rainforest, secondary forest, farm bush, woodlands, swamp forest, mangrove forest, abandoned treecrop plantations and reserved and degraded forest reserves;

- High presence of biodiversity, with huge potential for international tourist attraction.

- Strong potential for community involvement in the forestry sector, supported by fertile soil for the growth of Participatory Forest Management [PFM] and REDD + programmes.

- Potential for high level of tree crop farming including cocoa, coffee and rubber farms.

- Preliminary expression of interest and a large potential client base for the purchase of future credits as initiated in Sierra Leone.

- High prospects for the creation of job opportunities, more so sustainable employment for those in rural and forest dependent communities, who for quite a while may not have had the opportunity of being gainfully employed.

- Sierra Leone to recognize forestry as a climate change issue in her international

- UNFCCC negotiation process; an intervention strategy for the inclusion of REDD into the Kyoto Protocol and, subsequently into, the CDM.

\section{CONCLUSIONS}

PES is a challenge in testing an economy's endurance / strengths in battling with the possible future prospects of reversing a collapsed environmental system to a more sustainably managed environment for the benefit of present and future generations. Though the process is voluntary in nature, communities and the government of Sierra Leone must be ready to endure the strains of imposed conditions, which in most cases may create delay in payment received, after being cleared off three rigorous test conditions. The difficulty associated with the PES programme is the fact that failure in meeting one of the conditions may result in non-payment, which eventually may impact adversely on livelihoods for those considered too highly dependent on forest renewable resources such as Timber and Non-timber products. 
Recommendations in ensuring a successful implementation of the programme, with reference to Sierra Leone are highlighted below:

- Ensuring contingency funds are kept aside for the benefit of the poor and residents in rural communities, more so for Public-Private and Private PES related programmes. This will make it possible for those highly dependent on Forest resources for their basic livelihoods to secure temporary and short term sources of activities to meet basic household needs, for example, meeting the cost of children's education, and the financing of daily household chores.

- Ensuring people are fully aware about the details of PES conditionality; in such situation, it is absolutely vital that (legal) documents are transcribed in local vernacular or an interpreter is used to make it possible for those participating in the voluntary plan are fully aware about challenges, and as well future opportunities.

- Ensuring basic education is incorporated as part of PES initial programme implementation to raise awareness about all required stages, and as well as the different activities that may be involved once the programme is fully implemented. As expressed by Goulder and Pizer (2006: 6), 'Act today or Wait for Better Information' - uncertainty raises questions about the cost of mitigating climate change issues, on account of the continued destruction caused to the environment, through activities like deforestation perpetrated by mankind. Hence, on application of economic theory, the absence of fixed costs and irreversibility(ies) [high costs associated with destruction caused to the environment], mitigation can be made possible

\section{REFERENCES}

1. Akiwumi, F. A. (2006a) "Conflict Timber, Conflict Diamonds: Parallels in the Political Ecology of 19th and 20th Century Resource Exploitation in Sierra Leone." in Kwadwo Konadu-Agyemang, ed. Africa's Development in the Twenty-first Century: Pertinent Socio-Economic and Development Issues. Aldershort: Ashgate.

2. Akiwumi, F. A. (2006b) Environmental and Social Change in Southwestern Sierra Leone: Timber Extraction (1832-1898) and Rutile Mining (19672005). PhD Dissertation, San Marcos: Texas State University.

3. Alieu, E.K (2001] Forestry Outlook Studies in Africa [FOSA] Sierra Leone [FAO].

4. Alieu, E.K. (Online - n/d). Country perspective - Sierra Leone. Available at: <http://www.cfainternational.org/country_report_3.php $>$. (Accessed: 25th October 2015).

5. Alldridge, T. J. A. (1910). Transformed colony: Sierra Leone as it was, and as it is its Progress Peoples, Native Customs and Undeveloped Wealth. London: Seeley and Co. Limited.

6. Amazon Web Services (n/d). Sierra Leone: Forestry Policy 2010. Available at: $<$ https://s3-eu-west1.amazonaws.com/rdwebsite/slforestry/ForestryPolicy Final_21July2010.pdf>. (Accessed: 28th October 2015 . at a point where expected marginal costs and benefits are equal. In this situation, the introduction of basic education to alert communities and forest users about the aforementioned technicalities will help raise awareness about the seriousness of PES as a means to preserving the environment, while at the same time maintaining sustainable means of livelihoods for the benefit of users / those depending on renewable forest resources.

- Fostering community cohesion amongst rural or forest dwellers as a way of raising awareness of the full benefits of different (agricultural) activities considered necessary as part of the implementation and monitoring of PES. Through this, the acquisition of leadership skills can also be an opportunity for community members, thereby making it possible for negotiation to be established between PES beneficiaries and forest managers $\backslash$ government representatives. There is all chances that community cohesion can also help address ways of accessing less stringent means of funding PES through negotiation with government-led institutions like the central bank / other financial intermediaries as seen in the case with Islamic Development Bank through their department finance model (Beck, Demirgüç-Kunt and Merrouche, 2010). Where profitability is kept at a minimum, it is possible for people to gain access to easy means of financing development funds in support of their initiatives. In such a case, interest rates charged should be made infinitesimal, or capped to maximum for all recipients, be it individual or community-led organisations.

7. Baker, G., Smith, J.J., Cowan, D.A. (2003). Review and re-analysis of Domain-specific $16 \mathrm{~S}$ primers, JOURNAL OF MICROBIOLOGICAL METHODS, 55 (3): 541-555. doi:10.1016/j.mimet.2003.08.009.

8. Barkawi, A and Monnin, P. (2015). Monetary Policy and Sustainability - The Case of Bangladesh. Council on Economic Policy [CEP], Discussion Notes, 2015/1

9. Beck, T.; Demirgüç-Kunt, A, and Merrouche, Q. (2010). Islamic vs. conventional banking: business model, efficiency and stability. World Bank Group Policy Research Working Paper. http://dx.doi.org/10.1596/1813-9450-5446.

10. Becker, L. C. (2001) "Seeing green in Mali's woods: colonial legacy, forest use and local control." Annals of the Association of American Geographers 91:(3): pp. 504-526.

11. Beeyers, M.D (2012). "Forest resources and peacebuilding: Preliminary lessons from Liberia and Sierra Leone". In: Lujala, P and Rustad, S.A. (eds.), High-Value Natural Resources and Peacebuilding, pp. $467-390$.

12. Brown, O \& Crawford, A (2012). Conservation and Peace-building in Sierra Leone, International Institute for sustainable Development (iisd). Accessed in:http://www.iisd.org/pdf/ 2012/ iisd_conservation_in_Sierra_Leone.pdf (Date Accessed: 26th October 2015).

13. CDC (2015). New CDC investment to boost timber production and job creation in Sierra Leone and Ghana. Available 
http://www.cdcgroup.com/Media/News/New-CDCinvestment-to-boost-timber-production-and-jobcreation-in-Sierra-Leone-and-Ghana-

/\#sthash.hQmnliFs.dpuf. (Accessed: $15^{\text {th }}$ March 2016).

14. Centre for Environment Education (2007). Sustainable Development: An Introduction (Volume 1). Available: $<$ http://www.sayen.org/volume-i.pdf $>$. Accessed: 31st August 2015).

15. CIFOR (n/d). Forest and Livelihoods (LIV) Programme Strategy. Available at: $<$ http://www.cifor.org/publications/pdf_files/research/ livelihood/liv_strategy.pdf. (Accessed: 1st March 2016).

16. Cole, N.H.A. (1968). "The vegetation of Sierra Leone". Njala, Sierra Leone, Njala University College Press.

17. Conway, D. and O'Sullivan, R. (2011). Gola Forest REDD Project: Analysis of Legal Issues. Report produced by Climate Focus on behalf of the Royal Society for the Protection of Birds (RSPB). Washington D.C.

18. Creek, A, and Nakhooda, S. (2011). REDD+ Finance Delivery: Lessons from Early Experience. Climate Finance Policy Brief, ODI. Available at: $<$ http://www.odi.org/sites/odi.org.uk/files/odiassets/publications-opinion-files/7481.pdf $>$. (Accessed: 30th October 2015).

19. Davis, M. (2005) "Forests and conflict in Cambodia". International Forestry Review, 7: pp. 161-164.

20. de Jong, W., D. Donovan, and K. Abe, eds. 2007. Extreme conflict and tropical forests. Dordrecht, Netherlands: Springer.

21. Deen-Swarray, M., Adekunle, B and Odularu, G. (2013). Determinant of Deforestation in Sierra Leone 1980-2010. Available at:

$<$ http://aercafricaevents.org/papers/GroupE/E6\%20M ariama $\% 20$ Deen $\% 20$ Swarray $\% 20$

Bamidele \%20Adekunle\%20Gbadebo\%20OdularuNP.pdf $>$. (Accessed: 22nd October, 2015).

22. Department for Environment, Food and Rural Affairs (DEFRA, 2013). Payments for Ecosystem Services: A Best Practice Guide. Available at: $<$ https://www.gov.uk/government/uploads/system/upl oads/attachment_data/file/200920/pb13932-pesbestpractice-20130522.pdf $>$. (Accessed: 2nd October 2015).

23. Dorward, D. C. (1981). ANNUAL DEPARTMENTAL REPORTS RELATING TO SIERRA LEONE 18931961. Microform Academic Publishers: Wakefield, UK.

24. Dyson, F.J. (1977). CAN WE CONTROL THE CARBONDIOXIDE IN THE ATMOSPHERE? Energy Journal, Vol. 2: pp. 217-291.

25. Engel, S and Palmer, C. (2009). Designing Payments for Environmental Services with Weak Property Rights and External Interests. In L. Lipper, T. Sakuyama, R. Stringer and D. Zilberman, ed., 'PAYMENT FOR ENVIRONMENTAL SERVICES IN AGRICULTURAL LANDSCAPES: ECONOMIC POLICIES AND POVERTY REDUCTION IN DEVELOPING COUNTRIES'. Food and Agriculture Organization of the United Nations and Springer SciencepBusiness Media, LLC. IEcosystem Marketplace (2015). Full Circle: REDD and Indigenous People - Past, Present, and Future. Available at: $<\quad$ http://www.forest- trends.org/documents/files/doc_4942.pdf>. (Accessed: $15^{\text {th }}$ March 2016).

26. FAO (2007). The State of Food and Agriculture 2007. Part I: Paying farmers for environmental services. Food and Agriculture Organization of the United Nations (FAO), Rome. Available at: $<$ http://www.fao.org/docrep/010/a1200e/a1200e00. htm $>$. (Accessed: 14 ${ }^{\text {th }}$ March 2016).

27. FAO (2013). Multi-Stakeholder Dialogue on Remuneration of Positive Externalities (RPE)/Payments for Environmental Services (PES). Available http://www.fao.org/fileadmin/user_upload/pesproject/docs/FAO_PESMeeting1213Sept_Agenda.pdf. (Accessed: 10 ${ }^{\text {th }}$ March 2016).

28. FD/SL (1913) Report on the Forest Administration for the Year 1912, Forestry Department of Sierra Leone, London: Waterlow and Sons Limited.

29. GEF (2008). Payments for Environmental Services and the Global Environment Facility. A Scientific and Technical Advisory Panel (STAP) Advisory Document. Available at: http://www.thegef.org/gef/sites/thegef.org/files/docum ents/C.35.Inf_.12_STAP_Guidance_o n_PES.pdf $>$. (Accessed: $13^{\text {th }}$ March 2016).

30. Global Climate Change Alliance+ (n/d). REDD+ Capacity Building in Sierra Leone. Available at: $<$ http://www.gcca.eu/national-programmes/africa/gccasierra-leone $>$. (Accessed: $12^{\text {th }}$ March 2016).

31. Goulder, L.H., and Pizer, W.A. (2006). The Economics of Climate Change. Discussion Paper, RFF DP 06-06. Available

at:http://www.rft.org/files/sharepoint/WorkImages/Do wnload/RFF-DP-06-06.pdf\#pages4. (Accessed: 15 March 2016).

32. Government of Sierra Leone (2010). Millennium Development Goals Progress Report 2010: Concept Note 10 - National Climate Change Mitigation Strategy for Sierra Leone, Advise to GOSL on the implementation of REDD+. Government of Sierra Leone, Freetown. Available at: < http://www.adaptationundp.org/sites/default/files/downloads/seirra_leonnere dd_strategy.pdf $>$. (Accessed: $15^{\text {th }}$ March 2016).

33. Homer-Dixon, T. (1991). On the threshold: Environmental changes as causes of acute conflict. International Security 16:76-116.

34. IMF (2009). Sierra Leone: Selected Issues and Statistical Appendix (IMF Country Report No. 09/12). Available at: $<$ https://www.imf.org/external/pubs/ft/scr/2009/cr091 2.pdf $>$. (Accessed: 24th October 2015).

35. IUCN. (1993). ENVIRONMENTAL SYNOPSIS: Sierra Leone. Available at: $<$ https://portals.iucn.org/library/sites/library/files/docu ments/Co-SL-Env-004_.pdf $>$. (Accessed: 30th October 2015).

36. Jackson, E.A (2015b). Deforestation in the Freetown Peninsula - A case of livelihood and biodiversity loss in the Goderich community. International Journal of Agriculture and Forestry, Vol. 2(7): pp. 21 - 34.

37. Jackson, E. A (2015a). Negotiating New Dimensions for Forests Conservation in Sierra Leone. Journal of Applied Thoughts, Vol. 4 (2): 85-102).

38. Jackson EA (2015c) Ethnographic Narrative of Forest Decline in the Goderich Community: The People's 
Perspectives. Forest Res 4:157. doi:10.4172/21689776.1000157.

39. Jackson, E.A. (2015d). FLEGT Mandate: its applicability and effectiveness in Sierra Leone. Journal of Applied Thought, Vol. 4 (4): pp. 84-100.

40. Jackson EA (2015e) A Reflective Commentary on the Economics of Climate Change Mitigation. Forest Res 4:142. doi: 10.4172/2168-9776.1000142.

41. Jackson, E. A. (2016). Ontological and Epistemological Discourse(s) on Sustainable Development: Perspective on Sierra Leone in the Aftermath of a Decade of Civil Unrest. Journal of Management and Sustainable Development, Vol. 8(1): pp. 35-43. https://doi.org/10.1515/msd-2016-0005.

42. Jackson, E.A. and Jabbie, M. (2020). Twin Deficits hypothesis as an indication of government failure in Sierra Leone: An empirical investigation (2007 to 2018). Journal of Economic Policy Researches, Vol. 7(1): pp. 43-68. https://doi.org/10.26650/JEPR658440.

43. Jackson, E.A. (2021a). Sustainable Livelihood Framework (SLF) for Equitable Living in Crisis of Global Pandemic. In, In: Leal Filho W., Azul A., Brandli L., Lange Salvia A., Ozuyar, P.G., Wall, T. (ed.), Reduced Inequalities: Encyclopedia of Sustainable Development Goal, Springer Nature Publisher. DOI: 10.1007/978-3-319-71060-0_124-1.

44. Jackson, E.A. (2021b). Forecasting COVID-19 daily contraction in Sierra Leone with implications for Policy Formulation. Journal of Economic Policy Researches, Vol. 8(1): pp. 1-16. https://doi.org/10.26650/JEPR795665.

45. July, R.W. (1970), A History of the African People, Scribner, New York.

46. Kaimowitz, David, (2003) Forests and war, Forests and peace. Bogor, Indonesia: CIFOR.

47. Kaplan, R. (1994). The coming anarchy: How scarcity, crime, overpopulation and diseases are rapidly destroying our planet. Atlantic Monthly. February).

48. Konteh, W (1997). Forest Resource Management in Sierra Leone: A Critique of Policy Formulation and Implementation. Unpublished $\mathrm{PhD}$ Thesis. University of Leeds.

49. Lane-Poole C. E. (1911). Report on the forest of Sierra Leone. London: Waterlow and Sons Limited.

50. Leach, M. and J. Fairhead. (1994) "Natural resource management: the reproduction and use of environmental misinformation in Guinea's forestsavanna transition zone." IDS Bulletin 25:(2): pp. 8187.

51. Leach, M. and J. Fairhead. (1995) "Ruined settlements and new gardens: gender and soil-ripening among Kuranko farmers in the forest-savanna transition zone." IDS Bulletin 26:(1): pp. 24-32.

52. Leach, M. and J. Fairhead. (2000). Challenging neoMalthusian deforestation analyses in West Africa's dynamic forest landscapes. Population and Development Review 26(1): 17-43.

53. Lipper, L., McCarthy, N., and Zilberman, D. (2009). Putting Payments for Environmental Services in the Context of Economic Development, In Leslie Lipper, Takumi Sakuyama and David Zilberman ed., 'Payment for Environmental Services in Agricultural Landscapes. Natural Resource Management and Policy, FAO and Springer Publication.

54. Lipper, L, and Neves, B. (2011). Payments for environmental services - What role in sustainable agricultural development? ESA Working Paper No. 1120, December 2011. Agricultural Development Economics Division, Food and Agriculture Organization of the United Nations.

55. MacGregor, W.D. (1942). "The forest production programme in Sierra Leone". Farm and Forest, 3(3), 116-19.

56. Meredith, D. (1986) "State Controlled Marketing and Economic "Development": The Case of West African Produce during the Second World War." The Economic History Review 39:(1): pp. 77-91.

57. Mula, M.G and Saxena, K.B (2010). Lifting the Level of Awareness on Pigeonpea - A Global Perspectives. India: International Crops Research Institute for SemiArid Tropics. (Also available at: http://oar.icrisat.org/193/1/296_10_Lifting_eh_level_ of_awareness_on_Pigeonpea.pdf).

58. Munro, P.G. (2008) The Politics of Deforestation on the Freetown Peninsula, Masters Thesis, King's College London.

59. Munro, P. G. (2009) Deforestation: constructing problems and solutions on Sierra Leone's Freetown Peninsula. Journal of Political Ecology, Vol. 16: 104 122.

60. Munro, P.G and Horst, G, H (2011). Conserving Exploitation? A political ecology of forestry policy in Sierra Leone. ARAS, Vol. 32(1): 59 - 78.

61. Mvondo, S. A. and P. R. Oyono. (2004) "An assessment of social negotiation as a tool of local management: a case study of the Dimako Council forest, Cameroon." Scandinavian Journal of Forest Research 19(4): pp. 7884.

62. Najam, A (2002). Financing Sustainable Development: Crisis of Legitimacy. Progress in Development Studies, 2(2): pp. 153-160.

63. OECD (2010). Monitoring the Principles for Good International Engagement in Fragile States and Situations - Country Report 5: Sierra Leone. Available at: <Country Report 5: Sierra Leone>. (Accessed: 23rd October 2015).

64. Reed, T. and Robinson, J.A. (2013). The Chiefdoms of Sierra Leone. Available at: $<$ http://scholar.harvard.edu/files/jrobinson/files/histor y.pdf $>$. (Accessed: 23rd October 2015).

65. ReliefWeb (n/d). Map of Sierra Leone (Population Density as of October 2014). Available at: $<$ http://reliefweb.int/sites/reliefweb.int/files/resources/ MA014 PopulationDensity-300dpi.pdf.pdf>. (Accessed: 23rd October 2015).

66. Reno, W. (1998). Warlord politics and African states. Boulder, CO: Lynne Rienner.

67. Reno, W. (2000). Shadow states and the political economy of civil wars. In Greed and grievance: Economic agendas in civil war, ed. M. Bergdal and D. M. Malone. Boulder, CO: Lynne Rienner.

68. Ribot, J. \& Cline-Cole, R.A. (1997). "Forest policy, West Africa". In Press. J. Middleton, et al., Encyclopaedia of Africa South of $\backslash$ the Sahara.

69. Ross, M. (2003) The natural resources curse: How wealth can make you poor. In Natural resources and violent conflict, ed. I. Bannon and P. Collier. Washington, D.C.: World Bank.

70. Shahbaz, B and Suleri, A.Q. (2009). "The Political Economy of Forest Management in Pakistan". In, Cronin, R. and Pandya, A. (ed.), Exploiting Natural Resources: Growth, Instability, and Conflict in the 
Middle East and Asia, Stimson Center: Washington, D.C., pp. 21 - 35.

71. Suma, M. (2009), Charles Taylor and the Legacy of the Special Court for Sierra Leone, International Center for Transi- tional Justice, The Hague, available at www.ictj.org/static/Publications/bp_suma_impunity_r ev3.pdf. Accessed: 24th October 2015.

72. The World Law Guide (Online). Legislation Sierra Leone. Available at: <http://www. lexadin.nl/ wlg/legis/nofr/oeur/lxwesle.htm $>$ [Accessed: 26th October, 2015].

73. Trip Mondo website (n/d). Map of Freetown Peninsula. Available at: <http://www.tripmondo.com/sierraleone/western- area/bammbatuk/attractions-inbammbatuk/>. (Accessed: 20th October 2015).

74. Truth and Reconciliation Commission (2004), Witness to Truth: Report of the Sierra Leone Truth and Reconciliation Commission, Truth and Reconciliation Commission, Sierra Leone, available at www.sierraleone.org/TRCDocuments. html.

75. United Nations (1992). Rio Declaration on Environment and Development 1992. Available at: $<$ http://www.jus.uio.no/lm/environmental.developmen t.rio.declaration.1992/portrait.a4.pdf $>$. Accessed: 30th August 2015

76. UN Economic and Social Commission for Asia and the Pacific [ESCAP] (2012). Green Growth Resources and Resilience - Environmental Sustainability in Asia and the Pacific. Available at: $<$ http://www.adb.org/sites/default/files/publication/29 567/green-growth-resources-resilience.pdf $>$. (Accessed: 14 ${ }^{\text {th }}$ March 2016).

77. UNEP (2010). Sierra Leone Environment, Conflict and Peace-building Assessment: Technical Report. Châtelaine: Geneva.

78. UNEP (2010a). Frequently Asked Questions and Answers: The UN-REDD Programmes and REDD+. Available at: $<$ http://www.unep.org/forests/Portals/142/docs/UNREDD\%20FAQs\%20[11.10].pdf. (Accessed: 2nd March 2016).
79. UNIPSIL (2006). Ethnic Groups of Sierra Leone. Available

at: $<$ http://unipsil.unmissions.org/portals/unipsil/sierral eone/maps/sl_ethnic_groups.pdf $>$. (Accessed: 25th October 2015).

80. Unwin, A. H. (1909). Report on the forestry problems in Sierra Leone. London: Waterlow and Sons.

81. USAID (n/d). PROPERTY RIGHTS AND RESOURCE GOVERNANCE: Sierra Leone. Available at: $<$ http://www.usaidlandtenure.net/sites/default/files/co untry-profiles/full-

reports/USAID_Land_Tenure_Sierra_Leone_Profile.p df nv>. (Accessed: 29th October 2015).

82. United States Agency for International Development (USAID - n/d). FORESTS AND CONFLICT: ATOOLKIT FOR PROGRAMMING. Available at: $<$ http://pdf.usaid.gov/pdf_docs/Pnade290.pdf $>$. (Accessed: 25th October 2015.

83. United States Agency for International Development (USAID - n/d). FORESTS AND CONFLICT: ATOOLKIT FOR PROGRAMMING. Available at: $<$ http://pdf.usaid.gov/pdf_docs/Pnade290.pdf $>$. (Accessed: 25th October 2015).

84. Visit Sierra Leone (Online). Sierra Leone Background. Available at: $<$ https://www.visitsierraleone.org/backgroundinformation/history/Sierra-Leone-Background.html>. (Accessed: 26th October 2015).

85. Wardell, D. A. and C. Lund. (2006). "Governing access to forests in northern Ghana: micro-politics and the rents of non-enforcement." World Development 34:11, 1887-1906.

86. Wong, G. (2014). The experience of conditional cash transfers Lessons for REDD+ benefit sharing. Info Brief, No. 97.

87. Wunder, S. (2005). Payments for environmental services: some nuts and bolts. CIFOR occasional paper 42. Bogor, Indonesia: Center for International Forestry Research. 